\title{
PIDANA BERSYARAT PERSPEKTIF KITAB UNDANG-UNDANG HUKUM PIDANA DAN FIKIH
}

\author{
Moch Zainal Abidin \\ ebied86@gmail.com \\ SMP Drajat Baureno Bojonegoro
}

\begin{abstract}
This study aims to assess conditional criminal act in Criminal Code and Islamic jurisprudence. Conditional criminal act according to Criminal Code is a kind of crime where the convict does not have to undergo the punishment, except he has violated the general or specific requirenments of court during pre-determined. On the Islamic jurisprudence perspective, conditional criminal act is caterized as diyât and ta'zîr. Diyât is a kind of criminal penalty that provides a number of property within a certain size, given by the offender to the victim or his heirs. While ta'zîr is a legal authority delegated by state to a judge to decide the criminal cases. In ta'zîr, a judge has fairly broad authority to choose any types of crime that are appropriate to the circumstance of the offense and the perpetrators. Looseness or facilities provided to a judge do not reduce the initial goal of punishment as an attemp to improve the criminal actors in order to keep the benefit of people.
\end{abstract}

Keywords: Conditional criminal act, Criminal Code, Islamic jurisprudence.

\begin{abstract}
Abstrak: Artikel ini mengkaji tentang pidana bersyarat dalam Kitab Undang-Undang Hukum Pidana dan fikih. Pidana bersyarat menurut Kitab Undang-Undang Hukum Pidana, merupakan suatu pidana di mana terpidana tidak usah menjalani pidana tersebut, kecuali bilamana selama masa percobaan terpidana telah melanggar syarat-syarat umum atau khusus yang telah ditentukan oleh pengadilan. Jika dianalisis dari sisi fikih, pidana bersyarat dikatagorikan masuk dalam diyât dan ta'zîr. Diyât merupakan suatu jenis pidana yang memberikan sejumlah harta dalam ukuran tertentu, yang diberikan pelaku tindak pidana kepada korban atau ahli warisnya. Sedangkan ta'zîr merupakan kekuasan dalam memutuskan suatu perkara diserahkan kepada negara dan selanjutnya diserahkan kepada hakim. Di dalam ta'zîrini, hakim mempunyai wewenang yang cukup luas untuk memilih jenis pidana yang sesuai dengan keadaan tindak pidana serta diri pelakunya. Kelonggaran atau kemudahan yang diberikan kepada hakim tidak mengurangi tujuan awal dalam setiap pemidanaan, sebagai wujud memperbaiki diri pelaku demi terjaganya kemaslahatan di dalam masyarakat.
\end{abstract}

Kata Kunci: Pidana bersyarat, Kitab Undang-Undang Hukum Pidana, fikih 


\section{Pendahuluan}

Membahas kajian terhadap hukum pidana, tidak dapat dipisahkan dari pembahasan mengenai sanksi pidana yang dikenakan bagi para pelaku tindak pidana. Para pakar hukum pidana mengutarakan bahwa tujuan hukum pidana adalah: Pertama, untuk menakut-nakuti orang agar jangan sampai melakukan kejahatan (prepentive). Kedua, untuk mendidik atau memperbaiki orang-orang yang sudah menandakan suka melakukan kejahatan agar menjadi orang yang baik tabi'atnya (represiff). ${ }^{1}$ Oleh karena itu, penjatuhan pidana bukan sekedar berat ringannya pidana, akan tetapi juga pidana itu efektif atau tidak dan pidana itu sesuai dengan nilai-nilai dan struktural yang hidup dan berkembang di masyarakat.

Bahwa hukuman atau proses pemidanaan yang sesuai dengan apa yang diperbuat si pelaku dan dapat membuat pelaku jera serta menjadikan pelaku berubah ke arah yang lebih baik, hal tersebut merupakan suatu bagian penting dalam mewujudkan penegakan hukum. Ini dapat terlihat dari hasil yang dicapai.

Akan tetapi, dilihat dari keadaan dewasa ini proses penegakan hukum masih terlihat maju mundur. Dalam artian bahwa pencapaian suatu nilai keadilan pada masa sekarang ini masih sangat digantungkan pada kebijaksanaan dan kewibawaan para aparat penegak hukum. ${ }^{2}$ Dalam hal ini berkaitan dengan Kitab Undang-Undang Acara Pidana (KUHAP) memberikan suatu kebebasan kepada aparat penegak hukum, antara lain jaksa sebagai penuntut umum untuk menuntut seorang terdakwa, yang menurutnya secara sah dan meyakinkan telah melakukan sebuah tindak pidana sesuai dengan ketentuan hukum yang mengaturnya. Ketentuan tersebut juga berlaku untuk hakim sebagai pemberi keputusan atas suatu tindak pidana. Namun dalam menjatuhkan putusan terhadap suatu perkara terutama perkara pidana, hakim harus mempertimbangkan banyak hal. Dalam artian ketika hakim melaksanakan tugasnya antara hukum dan keadilan tidak boleh menyimpang dari aturan normatif yang berlaku. Tetapi juga hakim dapat memutus suatu perkara dengan memandang sisi sosiologis dari sebuah perkara.

\footnotetext{
1 Wirjono prodjodikoro, Asas-asas Hukum Pidana di Indonesia (Bandung: PT Refika Aditama, 2003), 20.

${ }^{2}$ Soerjono Soekanto dan Mustafa Abdullah, Sosiologi Hukum di dalam Masyarakat (Jakarta: Rajawali, 1987), 10.
} 
Penegakan hukum dalam perkara pidana pada suatu negara dapat dikatakan berhasil, tidak hanya semata-mata hakim yang menangani perkara pidana tersebut telah menjatuhkan sanksi pidana yang adil, baik bagi si korban maupun bagi si pelaku sendiri. Namun perlu juga diperhatikan bahwa putusan yang menyangkut penjatuhan sanksi pidana tersebut, seyogyanya dapat diterapkan sebagai tindakan untuk merubah perilaku salah (menyimpang) yang dilakukan oleh pelaku tersebut.

Pidana bersyarat merupakan jenis pidana yang memberi kesan sebagai solusi dari suatu bentuk tindak pidana yang dijatuhkan oleh hakim bagi seseorang agar tidak muncul pengaruh yang buruk yang lebih berbahaya lagi bagi orang tersebut apabila dimasukan kedalam lembaga permasyarakatan, sehingga hal ini hakim mempertimbangkan pengaruh pidana terhadap masa depan pelaku tindak pidana. ${ }^{3}$ Perlu diketahui bahwa dalam pemidanaan bersyarat setiap seorang terpidana yang telah dijatuhi pidana tertentu yang berkekuatan hukum tetap tidak diharuskan menjalani pidananya di dalam lembaga permasyarakatan, akan tetapi ia dapat berada di luar penjara. Tetapi perlu dicatat terpidana tersebut tidak serta merta bebas begitu saja, melainkan ia mempunyai dan diikat dengan syarat-syarat tertentu yang telah ditetapkan oleh majelis hakim.

Ketentuan-ketentuan yang mengatur tentang masalah pidana bersyarat ada dalam Pasal 14 A - 14 F Kitab Undang-Undang Hukum Pidana (KUHP) dan ditambahkan kedalam KUHP dengan Staatsblad tahun 1926 nomor 251 Jo nomor 486 dan mulai diberlakukan di Indonesia pada tanggal 1 Januari 1927.4

Walaupun sering disebut dengan pidana bersyarat (Voorwaardelijke Veroordeling), tetapi sesungguhnya bukan salah satu jenis pidana, karena tidak disebut dalam pasal 10 KUHP. ${ }^{5}$ Maka pidana bersyarat dapat dikatakan sebagai suatu sistem penjatuhan pidana tertentu.

Pidana bersyarat dalam hukum pidana Islam termasuk dalam kategori jarîmah ta'zîr dan diyât. Karena ta'zîr tidak ditentukan di dalam al-Qur'an ataupun as-Sunnah, sehingga penetapan hukuman jarîmah adalah wewenang 'ulil amri (penguasa) berdasarkan kemaslahatan umat.

\footnotetext{
3 Muladi, Kapita Selekta Sistem Peradilan Pidana (Semarang: Badan Penerbit Universitas Diponogoro, 1995 ), 105.

${ }^{4}$ P.A.F Lamintang, Hukum Penitensier Indonesia (Bandung: Amrico, 1984), 148.

${ }^{5}$ Adami Chazawi, Pelajaran Hukum Pidana (Bagian 1) Jakarta: PT Raja Grafindo Persada, 2002), 54.
} 
Hukuman ta'zîr adalah hukuman yang bersifat mencegah, menolak timbulnya bahaya. Apabila tujuan diadakannya ta'zîr itu demikian, maka jelas sekali hal itu ada dalam al-Qur'an dan as-Sunnah, karena setiap perbuatan yang merusak dan merugikan orang lain hukumnya dilarang. Ta'zîr Adalah bentuk hukuman yang tidak disebutkan ketentuan kadar hukumnya oleh shara' dan menjadi kekuasaan wali al-amri atau hakim. Sebagaimana dikemukakan oleh AlMawardi sebagai berikut:

Ta'zîr adalah hukuman pendidikan atas dosa (tindak pidana) yang belum ditentukan oleh hukuman shara.'

Dari definisi tersebut, dapat diketahui bahwa hukuman ta'zîr adalah hukuman yang belum ditetapkan oleh shara', dan wewenang untuk menetapkannya diserahkan kepada ulil amri. Pengertian diyât sebagaimana dikemukakan oleh Sayid Sabiq sebagai berikut:

Diyât adalah sejumlah harta yang dibebankan kepada pelaku, karena terjadinya tindak pidana (pembunuhan atau penganiayaan) dan diberikan kepada korban atau walinya. ${ }^{7}$

Dari definisi tersebut jelaslah bahwa diyât merupakan uqûbah mâliyyah (hukuman yang bersifat harta), yang diserahkan kepada korban apabila ia masih hidup atau kepada, wali (keluarganya) apabila ia sudah meninggal, bukan kepada pemerintah. Dasarnya adalah Firman Allah swt surat An-Nisa ayat 92:

"Dan tidak layak bagi seorang mukmin membunuh seorang mukmin (yang lain), kecuali karena tersalah (tidak sengaja), dan barangsiapa membunuh seorang mukmin karena tersalah (hendaklah) ia memerdekakan seorang hamba sahaya yang beriman serta membayar diyât yang diserahkan kepada keluarganya (si terbunuh itu), kecuali jika mereka (keluarga terbunuh) bersedekah. Jika ia (si terbunuh) dari kaum (kafir) yang ada Perjanjian (damai) antara mereka dengan kamu, Maka (hendaklah si pembunuh) membayar diyât yang diserahkan kepada keluarganya (si terbunuh) serta memerdekakan hamba sahaya yang beriman. Barangsiapa yang tidak memperolehnya, maka hendaklah ia (si pembunuh) berpuasa dua bulan berturut-

\footnotetext{
${ }^{6}$ Abu Al-Hasan Ali Al-Mawardi, Kitab al-Ahkâm as-Sultâniyyah (Beirut: Dar Al-Fikr, 1966), 236.

${ }^{7}$ Sayid Sabiq, Fikih Sunnah, Jilid 10 (Bandung: PT. Alma'arif, 1987), 465.
} 
turut untuk penerimaan taubat dari pada Allah. Dan adalah Allah Maha mengetahui lagi Maha Bijaksana. (QS. An-Nisa ayat 92). ${ }^{8}$

Menurut penjelasan ayat di atas, hukuman diyât dikenakan kepada pelaku pembunuhan karena kesalahan, namun di sini kedudukannya sebagai hukuman pokok. Adapun penerapannya untuk pembunuhan sengaja merupakan hukuman pengganti yang diperkuat oleh hadist Nabi saw. Dikutip oleh Ahmad Wardi Muslich dalam bukunya, Hukum Pidana Islam, sebagai berikut:

"Dari Abi Syuraih al-Khuza'i ia berkata: telah bersabda Rasulullah saw: Maka barang siapa yang salah seorang anggota keluarganya menjadi korban pembunuhan setelah ucapanku ini, keluarganya memiliki dua pilihan: Adakalanya memilih diyât, atau memilih qisâs (hukum bunuh)." (HR. Abu Daud dan Nasa'i). ${ }^{9}$

Menurut penulis masalah pidana bersyarat merupakan suatu hal yang menarik untuk disimak dan dicermati, karena pidana bersyarat merupakan suatu putusan peradilan yang berkekuatan hukum tetap, yang pada dasarnya merupakan produk pengadilan yang harus dipatuhi dan dijalankan sesuai dengan diperintahkan. Pidana bersyarat merupakan pidana bagi seorang terpidana yang telah dijatuhi pidana tertentu tetapi tidak diharuskan menjalani pidananya di dalam lembaga permasyarakatan melainkan ia dapat berada di luar penjara. Apabila dalam waktu tertentu terpidana tersebut di pidana karena melakukan tindak pidana yang lain maka pidana yang di jatuhkan kepadanya akan lebih berat, ini dikarenakan selain pidana yang dijatuhkan akibat tindak pidananya yang terakhir kemudian ditambah dengan pidana pokok yang disyaratkan sebelumnya, jadi jelaslah bahwa keberadaan hukum pidana bersyarat di sini bukan merupakan putusan bebas, akan tetapi lebih cenderung dititik beratkan kepada proses permasyarakatan terpidana. Di mana bukan tidak mungkin apabila putusan yang dijatuhkan adalah perampasan kemerdekaan seperti penjara maka akan membuat terpidana tersebut lebih "pandai" lagi dalam melakukan tindak pidana.

Tidak dapat dipungkiri masyarakat kita masih buta hukum dalam menafsirkan sebuah ketentuan (peraturan). Dan terkadang keadaan ini yang menjadikan sebuah permasalahan baru tentang persepsi keadilan. Karena keadilan sering kali ditafsirkn sebagai suatu pemenuhan rasa adil

\footnotetext{
${ }^{8}$ Departemen Agama RI, al-Qur'an dan Terjemahannya (Surabaya: Penerbit CV. Jaya Sakti, 1989), 135.

${ }^{9}$ Ahmad Wardi Muslich, Hukum Pidana Islam (Jakarta: Sinar Grafika, 2005), 167.
} 
(setimpal) terhadap perasaan yang dirasakan oleh korban. Padahal setiap individu baik itu pelaku tindak pidana ataupun korban dari tindak pidana mempunyai hak-hak dari rasa pemenuhan keadilan. Dari si pelaku mempunyai hak untuk diadili dan di dakwa sesuai apa yang diperbuatnya, begitu juga korban mendapatkan haknya untuk melihat si pelaku tindak pidana di jatuhkan putusan yang setimpal.

\section{Pengertian Jarîmah Ta'zîr}

Ta'zîr merupakan pemberian pengajaran atas perbuatan-perbuatan yang dilarang dan tidak disyariatkan hukuman hudûd atasnya, atau hukuman atas jarîmah-jarîmah yang belum ditentukan oleh shar'i hukumanya. ${ }^{10}$

Dimana ta'zîr merupakan sekumpulan hukuman yang belum ditentukan jumlahnya, yang dimulai dari hukuman yang paling ringan, seperti nasihat dan teguran, sampai kepada hukuman yang paling terberat, yaitu kurungan dan dera, bahkan sampai pada hukuman mati dalam tindak pidana berbahaya. Jadi, hukum Islam tidak menentukan macam-macam pidana dan pemidanaan untuk tindak pidana ta'zîr, dalam hal ini hakim diberi kebebasan untuk memilih pidana yang sesuai dengan macam tindak pidana ta'zîr serta keadaan si pelaku. Singkatnya pidana pada jarîmah ta'zîr tidak ditentukan banyaknya dan jumlahnya seperti jarîmah hudûd atau qisâs-diyât. Shara' hanya menentukan sebagian jarîmah ta'zîr, yaitu perbuatan-perbuatan yang selamanya akan tetap dianggap sebagai tindak pidana, seperti; riba, mengkhianati janji, memaki orang, menyuap dan sebagainya.

Adapun sebagian besar dari tindak pidana ta'zîr diserahkan kepada penguasa untuk menentukannya dengan maksud mengatur masyarakat dengan menjauhkan dari perbuatan maksiat (kemaslahatan umum) dan memelihara kepentingannya tanpa keluar atau berlawanan dengan shar'i.

Setelah melihat pemaparan di atas, perlu diketahui juga beberapa hal pentingnya pembagian jarîmah menjadi hudûd, qisâs-diyât, dan ta'zîr. Yaitu sebagai berikut: ${ }^{11}$

1. Segi pengampunan, pada jarîmah hudûd tidak ada pengampunan sama sekali, baik dari si korban maupun dari penguasa tertinggi (kepala negara).

\footnotetext{
${ }^{10}$ Alie Yafi, dkk, Ensiklopedi Hukum Pidana Islam, Jilid 3 (Jakarta: Kharisma Ilmu, 2007), 100.

${ }^{11}$ Ahmad Hanafi, Asas-Asas Hukum Pidana Islam (Jakarta: Bulan Bintang, 2005), 9-10.
} 
Adapun pada jarîmah qisâs, pengampunan dapat diberikanoleh si korban atau walinya. Dalam hal ini, pengampunan yang diberikan mempunyai pengaruh atau akibat hukum lain. Di mana si korban memberikan pemaafan pidana qisâs untuk diganti dengan pidana diyât sebagaimana ia juga bisa membebaskan si pelaku dari pidana diyât. Kepala negara dalam jarîmah qisâs tidak dapat memberikan pengampunan karena pengampunan disini hanya dimiliki (yang mempunyai hak) oleh jorban dan walinya.

Dalam jarîmah ta'zîr penguasa diberi hak untuk membebaskan si pelaku dari hukuman, dengan syarat tidak mengganggu hak pribadi dari si korban. Si korban juga bisa memberikan pengampunan dalam batas-batas yang berhubungan dengan hak pribadinya, tetapi hanya sebatas meringankan bukan menghapuskan pemidanaan karena jarîmah yang dilakukan si pelaku menyinggung hak masyarakat. Jadi di dalam jarîmah ta'zîr seorang hakim mempunyai kekuasaan dalam mempertimbangkan keadaan-keadaan yang meringankan serta peringanan pidana.

2. Segi kekuasaan Hakim, dalam jarîmah hudûd, apabila jarîmah sudah dapat dibuktikan maka hakim harus melaksanakan pidana yang telah ditentukan, tanpa mengurangi, menambah, mengganti, atau menunda pelaksanaannya. Artinya kekuasaan hakim dalam jarîmah hudûd hanya sebatas pembacaan putusan.

Pada jarîmah qisâs, kekuasaan hakim terbatas pada penjatuhan pidana yang telah ditetapkan, apabila perbuatan yang dituduhkan kepada si pelaku telah dapat dibuktikan. Kalau korban memaafkan si pelaku dari qisâs atau qisâs tidak dapat dilaksanakan karena alasan shar'i, maka hakim harus menjatuhkan pidana diyât kepada si pelaku selama si korban tidak memaafkannya dari diyât. Kalaupun diyât ini juga dibebaskan oleh korban kepada si pelaku, maka hakim dapat menjatuhkan pidana ta'zîr.

Adapun pada jarîmah ta'zîr, hakim mempunyai kekuasaan yang luas untuk memberikan jenis dan ukuran pidana, memberikan pemberatan atau peringanan pidana dan juga dapat menyegerakan ataupun menunda pelaksanaan pemidanaan.

3. Segi Keadaan-keadaan yang Meringankan (az-Zurûf alMukhfafafah), keadaan-keadaan yang meringankan hanya berpengaruh pada jarîmah ta'zîr. Sedangkan pada jarîmah hudûd, 
qisâs-diyât keadaan-keadaan yang meringankan tidak berpengaruh apapun, artinya pidana atas ketiga jarîmah tersebut tetap dilaksanakan bagaimanapun keadaan si pelaku.

4. Segi Pembuktian Jarîmah, dalam pembuktian sebuah jarîmah, baik hudûd, qisâs-diyât dan ta'zîr, hukum Islam mensyaratkan adanya saksi yang jumlahnya telah ditentukan. Jika pembuktiannya hanya berupa saksi-saksi seperti dalam jarîmah zina maka dibutuhkan empat orang saksi. Adapun jarîmah hudûd yang lain dan juga qisâs-diyât sedikitnya membutuhkan dua orang saksi. Sedangkan dalam jarîmah ta'zîr hanya diperlukan satu orang saksi.

\section{Dasar Hukum Disyariatkannya Jarîmah Ta'zîr}

Asal mula disyariatkannya hukuman ta'zîr adalah apa yang diriwayatkan oleh Abu Daud, At-Tirmidzi, An-Nasa'i dan Al-Baihaqi dari bahz ibnu Hakim dari ayahnya dari kakeknya, bahwa Nabi saw. Telah menjatuhkan hukuman kurungan (penjara) terhadap pelaku tuduhan palsu. Hadis ini dianggap shahih oleh Al-Hakim.

Akan tetapi hukuman kurungan seperti yang dilakukan Nabi saw tadi adalah sebagai tindakan preventif sampai perkaranya menjadi jelas.

Imam Bukhari dan Muslim serta Abu Daud meriwayatkan sebuah hadis dari Hani' ibnu Nayyaar, bahwa beliau pernah mendengar Rasulullah saw pernah bersabda:

"Janganlah kamu melakukan pemukulan lebih dari sepuluh kali cambukan, kecuali hanya dalam pelaksanaan hukuman had yang telah mendapat restu dari Allah swt."

Telah ditetapkan bahwa Khalifah Umar ibnu Khatab ra. melakukan hukuman ta'zîr dan hukuman yang bersifat edukatif, yaitu dengan mencukur gundul kepala, mengasingkan dan memukul. Sebagaimana beliau pun membakar warung-warung penjual khamar, dan membakar pula desa yang di dalamnya dijual khamar. Dan beliau juga membakar gedung Sa'ad ibnu Waqqash di Kufah, karena dia selalu menutupnya tidak memperkenankan rakyatnya masuk.

Kemudian beliau membuat cambuk yang khusus buat memukul orang yang berhak mendapatkan hukuman cambuk, membuat penjara, dan beliau memukul wanita yang menangisi kematian keluarganya, sampai rambutnya kelihatan. 
Para imam yang berjumlah tiga mengatakan, bahwa hukuman ta'zîr itu wajib dilaksanakan. Adapun Imam Syafi'i mengatakan, bahwa itu tidak wajib. ${ }^{12}$

\section{Hikmah Disyariatkannya Hukuman Ta'zîr serta Perbedaannya dengan Hukuman Had}

Islam mensyariatkan hukum ta'zîr sebagai tindakan edukatif terhadap orang-orang yang berbuat maksiat atau orang-orang yang keluar tatanan peraturan. Hikmahnya adalah sama dengan hikmah yang terdapat dalam hukuman had. Hanya saja hukuman ta'zîr ini berbeda dengan hukuman had karena tiga hal sebagai berikut:

1. Pelaksanaan hukuman had tanpa pandang bulu, lain dengan hukuman ta'zîr yang pelaksanaannya berbeda sesuai dengan kondisi masing-masing orang. Bilamana orang terhormat melakukan kesalahan, maka boleh dimaafkan dari kesalahannya. Dan seandainya dihukum, maka hendaknya hukuman tersebut lebih ringan dari hukuman yang ditimpakan terhadap orang lain dalam kasus yang sama yang mana orang tersebut lebih rendah kedudukan dan kemulianya dibanding dengan dia.

Imam Ahmad, Abu Daud An-Nasa'i dan Al-Baikhaqi meriwayatkan bahwa Rasulullah SAW. Pernah bersabda:

"Maafkanlah kesalahan orang-orang yang terhormat oleh kamu sekalian, kecuali dalam masalah hudûd (hukuman had)."

Artinya bilamana ada seorang lelaki yang tidak diketahui pernah berbuat kejelekan terpeleset melakukan kesalahan, atau belum pernah melakukan dosa-dosa kecil, atau dia terkenal ketaatannya dan dosa kecil yang dilakukannya sekarang, adalah yang pertama kalinya maka janganlah kamu menghukumnya. Dan bilamana kondisinya memang menuntut agar dia dihukum, maka hendaknya hukumanya adalah yang ringan saja.

2. Dalam kasus had tidak diperkenankan meminta grasi sesudah kasusnya dilaporkan kepada sang hakim, sedangkan dalam kasus hukuman ta'zîr hal itu diperbolehkan.

3. Sesungguhnya orang yang mati akibat hukuman ta'zîr, orang yang melaksanakannya harus bertanggung jawab terhadap kematiannya. Pernah terjadi Khalifah Umar menakut-nakuti seorang wanita

\footnotetext{
${ }^{12}$ Sayyid Sabiq, Fikih Sunnah, 160-161.
} 
sehingga wanita tersebut mengalami keguguran saking takutnya, akhirnya Umar ra. Menanggung diyât janinnya. Abu Hanifah dan Imam Malik mengatakan bahwa dalam kasus ini tidak ada ganti rugi dan tidak apa-apa, sebab pelaksanaan ta'zîr dan had sama saja. ${ }^{13}$

\section{Macam-Macam Hukuman Ta'zîr}

\section{Hukuman Ta'zîr yang Berkaitan dengan Badan}

\section{a. Hukuman Mati}

Untuk jarîmah ta'zîr, hukuman mati ini diterapkan oleh para fuqaha secara beragam. Hanafiyah membolehkan kepada ulil amri untuk menerapkan hukuman mati sebagai ta'zîr dalam jarîmah- jarîmah yang jenisnya diancam dengan hukuman mati apabila jarîmah tersebut dilakukan berulang-ulang. Contohnya pencurian yang berulang-ulang dan menghina Nabi beberapa kali yang dilakukan oleh kafir dzimmi, meskipun setelah itu ia masuk Islam.

Malikiyah juga membolehkan hukuman mati sebagai ta'zîr untuk jarîmah-jarîmah ta'zîr tertentu, seperti spionase dan melakukan kerusakan dimuka bumi. Pendapat ini juga dikemukakan oleh sebagian fuqaha Hanabilah, seperti Imam ibnu Uqail.

Sebagian fuqaha Syafi'iyah membolehkan hukuman mati sebagai ta'zîr dalam kasus penyebaran aliran-aliran sesat yang menyimpang dari ajaran Al-Qur'an dan as-sunnah. Demikian pula hukuman mati bisa diterapkan kepada pelaku homo seksual (liwât) dengan tidak membedakan antara muhsan dengan gair muhsan. Alasan yang dikemukakan oleh Syafi'iyah adalah hadist yang diriwayatkan oleh Ibnu Abbas bahwa Rasulullah saw bersabda:

"Barang siapa yang kamu dapati melakukan perbuatan kaum Nabi Luth (homo seksual) maka bunuhlah pelaku dan objeknya." (Hadis diriwayatkan oleh lima ahli hadist kecuali Nasa'i). ${ }^{14}$

Dari uraian tersebut jelas bahwa hukuman mati untuk jarîmah ta'zîr, hanya dilaksanakan dalam jarîmah-jarîmah yang sangat berat dan berbahaya, dengan syarat-syarat sebagai berikut:

13 Ibid., 161-162.

${ }^{14}$ Muhammad Ibn Ali Asy-Syaukani, Nail al-Autâr, Juz VII (Beirut: Dar Al-Fikr, tt.), 286. 
1) Bila pelaku adalah residivis yang tidak mempan oleh hukuman-hukuman hudûd selain hukuman mati.

2) Harus dipertimbangkan betul-betul dampak kemaslahatan terhadap masyarakat dan pencegahan terhadap kerusakan yang menyebar di muka bumi.

Adapun alat yang digunakan untuk melaksanakan hukuman mati sebagai ta'zîr tidak ada keterangan yang pasti. Ada yang mengatakan boleh dengan pedang, dan ada pula yang mengatakan boleh dengan alat yang lain, seperti kursi listrik. Namun kebanyakan ulama memilih pedang sebagai alat eksekusi, karena pedang mudah digunakan dan tidak menganiaya terhukum, karena kematian terhukum dengan pedang lebih cepat.

\section{b. Hukuman Jild (Dera)}

Alat yang digunakan untuk hukuman jilid ini adalah cambuk yang pertengahan sedang (sedang, tidak terlalu besar dan tidak terlalu kecil) atau tongkat. Pendapat ini juga dikemukakan oleh Imam ibn Taimiyah, dengan alasan karena sebaik-baiknya perkara adalah pertengahan. ${ }^{15}$

Adapun sifat atau cara pelaksanaan hukuman jilid masih diperselisihkan oleh para fuqaha. Menurut Hanafiyah, jilid sebagai sebagai ta'zîr harus harus dicambukan lebih keras dari jilid dalam had agar dengan ta'zîr orang yang terhukum akan menjadi jera, disamping karena jumlahnya lebih sedikit dari pada dalam had. Alasan yang lain adalah bahwa semakin keras cambukan itu semakin menjerakan. Akan tetapi, ulama selain Hanfiyah menyamakan sifat jilid dalam ta'zîr dengan sifat jilid dalam had.

Apabila orang yang dijilid itu laki-laki maka baju yang menghalangi sampainya cambuk kekulit harus dibuka. Akan tetapi, apabila orang terhukum itu perempuan maka bajunya tidak boleh dibuka, karena jika demikian akan terbukalah auratnya.

Pukulan atau cambukan tidak boleh diarahkan kemuka, farji, dan kepala melainkan diarahkan kebagian punggung. Imama Abu Yusuf menambahkan tidak boleh mencambuk bagian dada dan perut, karena pukulan kebagian tersebut bisa membahayakan keselamatan orang yang terhukum. Larangan pencambukan pada

\footnotetext{
${ }^{15}$ Ibn Taimiyah, Al-Siyâsah Al-Syar'iyah (Kairo: Maktabah Anshar Al-Muhammadiyah, 1961), 117.
} 
bagian kepala didasarkan pada atsar sahabat Umar yang mengatakan kepada eksekutor jilid

"Hindarilah untuk memukul kepala dan farji"

Dari uraian tersebut, dapat dipahami bahwa hukuman jilid tidak boleh sampai menimbulkan cacat dan membahayakan organ-organ tubuh orang yang terhukum, apabila sampai membahayakan jiwanya, karena tujuannya adalah memberi pelajaran dan pendidikan kepadanya. Oleh karena itu, pendapat yang mengatakan bahwa sasaran jilid dalam ta'zîr adalah bagian punggung tampaknya merupakan pendapat yang lebih kuat. ${ }^{16}$

\section{Hukuman yang Berkaitan dengan Kemerdekaan}

\section{a. Hukuman Penjara}

Atas dasar kebijakan Khalifah Umar ini, para ulama membolehkan kepada ulil amri (pemerintah) untuk mebuat penjara. Meskipun demikian para ulama yang lain tetap tidak boleh untuk mengadakan penjara, karena hal itu tidak pernah dilakukan Nabi maupun Abu Bakar.

Selain tindakan Khalifah Umar, dasar hukum untuk dibolehkannya hukuman penjara ini adalah surat An-Nisa' Ayat 15:

"Dan (terhadap) Para wanita yang mengerjakan perbuatan keji ${ }^{17}$ hendaklah ada empat orang saksi diantara kamu (yang menyaksikannya). kemudian apabila mereka telah memberi persaksian, Maka kurunglah mereka (wanita-wanita itu) dalam rumah sampai mereka menemui ajalnya, atau sampai Allah memberi jalan lain kepadanya." (QS. An-Nisa' ayat 15$){ }^{18}$

Disamping itu, alasan lain untuk dibolehkannya hukuman penjara sebagai ta'zîr adalah tindakan Nabi saw, yang pernah memenjarakan beberapa orang di Madinah dalam tuntutan pembunuhan. Juga tindakan Khalifah Ustman yang memenjarakan Dhabi' ibn Al-Harits, salah seorang pencuri Bani Tamim, sampai ia mati dipenjara. Demikian pula Khalifah Ali

\footnotetext{
${ }^{16}$ Ahmad Wardi Muslich, Hukum Pidana Islam, 260-261.

${ }^{17}$ Perbuatan keji: menurut jumhur mufassirin yang dimaksud perbuatan keji ialah perbuatan zina, sedang menurut pendapat yang lain ialah segala perbuatan mesum seperti: zina, homoseks dan yang sejenisnya. Menurut pendapat Muslim dan Mujahid yang dimaksud dengan perbuatan keji ialah musâhaqah (homoseks antara wanita dengan wanita).

${ }^{18}$ Departemen Agama RI, al-Quran dan Terjemahannya, 118.
} 
pernah memenjarakan Abdullah ibn Az-Zubair di Mekah, ketika ia menolak untuk membaiat Ali.

Hukuman penjara dalam syariat Islam dibagi kepada dua bagian, yaitu:

1) Hukuman penjara yang dibatasi waktunya;

2) Hukuman penjara yang tidak dibatasi waktunya.

\section{b. Hukuman Pengasingan}

Hukuman pengasingan ini dijatuhkan kepada pelaku jarîmah yang dikhawatirkan berpengaruh kepada orang lain sehingga pelakunya harus di buang (diasingkan) untuk menghindarkan pengaruh-pengaruh tersebut.

Adapun tempat pengasingan diperselisihkan oleh para fuqaha. Menurut Imam Malik ibn Anas, pengasingan itu artinya menjauhkan (membuang) pelaku dari negeri Islam ke negeri bukan Islam. Menurut Umar ibn Abdul Aziz dan Said ibn Jubair, pengasingan itu artinya dibuang dari suatu kota kekota yang lain. Menurut Imam Abu Hanifah dan satu pendapat dari Imam Malik, pengasingan itu artinya dipenjarakan. ${ }^{19}$

Lamanya (masa) pengasingan juga tidak ada kesepakatan dikalangan para fuqaha. Menurut Imam Syafi'iyah dan Hanabilah, masa pengasingan tidak boleh lebih dari satu tahun agar tidak melebihi masa pengasingan dalam jarîmah zina yang merupakan hukuman had. Apabila pengasingan dalam ta'zîr lebih dari satu tahun, ini berarti berlawanan dengan hadist Nabi saw, yang diriwayatkan oleh Imam al-Baihaqi dari Nu'man ibn Basyir bahwa Rasulullah saw, bersabda:

"Barang siapa yang mencapai (melaksanakan) hukuman had bukan dalam jarîmah hudûd, maka ia termasuk orang yang melampaui batas".

Menurut Imam Abu Hanifah masa pengasingan bisa lebih dari satu tahun, sebab pengasingan disini merupakan jarîmah ta'zîr, bukan hukuman had. Pendapat ini juga dikemukakan oleh Imam Malik. Akan tetapi, mereka tidak mengemukakan batas

${ }^{19}$ Ahmad Wardi Muslich, Hukum Pidana Islam, 264. 
waktunya dan menyerahkan hal itu kepada pertimbangan penguasa (hakim) ${ }^{20}$

\section{Hukuman Ta'zîr yang Berkaitan dengan Harta}

\section{a. Status Hukumnya}

Para ulama berbeda pendapat tentang dibolehkannya hukuman ta'zîr dengan cara mengambil harta. Menurut Imam Abu Hanifah, hukuman ta'zîr dengan cara mengambil harta tidak dibolehkan. Pendapat ini diikuti oleh muridnya, yaitu Muhammad ibn Hasan, tetapi muridnya yang lain, yaitu Imam abu Yusuf membolehkannya apabila dipandang membawa maslahah. Pendapat ini diikuti oleh Imam Malik, Imam Syafi'i, dan Imam Ahmad ibn Hanbal.

\section{b. Pengertiannya}

Para ulama yang membolehkan hukuman ta'zîr dengan cara mengambil harta, terutama dari Hanafiyah mengartikannya dengan redaksi:

"Hakim menahan sebagian harta si terhukum selama waktu tertentu, sebagai pelajaran dan upaya pencegahan atas perbuatan yang dilakukannya, kemudian mengembalikannya kepada pemiliknya apabila ia telah jelas taubatnya”.

Dari pengertian tersebut, jelaslah bahwa hukuman ta'zîr dengan mengambil harta itu bukan berarti mengambil harta pelaku untuk diri hakim atau untuk kas umum (Negara), melainkan hanya menahannya untuk sementara waktu. Adapun apabila pelaku tidak bisa diharapkan untuk bertobat maka hakim dapat mentasarufkan harta tersebut untuk kepentingan yang mengandung maslahah.

\section{c. Macam-Macamnya}

Imam Taimiyah membagi hukuman ta'zîr berupa harta ini kepada tiga bagian, dengan memerhatikan athar (pengaruhnya) terhadap harta:

1) Menghancurkannya

2) Mengubahnya), atau

3) Memilikinya)

${ }^{20} \mathrm{lbid}, 265$. 
Penghancuran terhadap barang sebagai hukuman ta'zîr berlaku dalam barang-barang dan perbuatan/sifat yang mungkar. Contohnya seperti:

a.Penghancuran patung milik orang Islam.

b. Penghancuran alat-alat musik/permainan yang mengandung maksiat.

c.Penghancuran alat dan tempat minuman khamr.

Khalifah Umar pernah menumpahkan susu yang tercampur dengan air untuk dijual, karena apabila susu dicampur dengan air maka sulit mengetahui kadar susu dari airnya.

Adapun hukuman ta'zîr yang berupa mengubah harta (pelaku), antara lain seperti mengubah patung yang disembah orang muslim dengan cara memotong bagian kepalanya, sehingga mirip dengan pohon.

Hukuman ta'zîr berupa pemilikan harta penjahat (pelaku), antara lain seperti keputusan Rasulullah saw melipatgandakan denda bagi seseorang yang mencuri buah-buahan, disamping hukuman jild. Demikian pula keputusan Khalifah Umar yang melipatgandakan denda bagi orang yang menggelapkan barang temuan.

Dari uraian yang telah dikemukakan di atas, khususnya pada bagian ketiga dari jenis ta'zîr dengan harta, dapat diketahui bahwa wujud dari pemilikan harta itu adalah denda atau dalam bahasa Arab disebut Garâmah. ${ }^{21}$

\section{Pengertian Pidana Bersyarat}

Pidana bersyarat yang biasa disebut dengan pidana perjanjian atau pidana secara jenggelan, yaitu menjatuhkan pidana kepada seseorang akan tetapi pidana itu tidak usah dijalani kecuali dikemudian hari ternyata terpidana sebelum habis masa percobaan melakukan tindak pidana lagi atau melanggar perjanjian yang diberikan oleh hakim. Jadi putusan pidana tetap ada hanya pelaksana pidana itu saja yang ditangguhkan. ${ }^{22}$

Sedangkan Muladi memberikan pengertian dari pidana bersyarat adalah:

${ }^{21}$ Ibid., 266-267.

${ }^{22}$ R. Soesilo, Pokok-Pokok Hukum Pidana (Bogor: Politea, t.th), 40. 
Suatu pidana dalam hal mana si terpidana tidak usah menjalani pidana tersebut, kecuali bila mana dalam masa percobaan terpidana telah melanggar syarat-syarat umum atau khusus yang telah ditentukan oleh pengadilan. Dalam hal ini pengadilan yang mengadili perkara tersebut mempunyai wewenang untuk melakukan perubahan-perubahan syaratsyarat yang telah ditentukan atau memerintahkan agar pidana dijalani. Pidana bersyarat ini merupakan penundaan terhadap pelaksanaan pidana. ${ }^{23}$

Maksud dari vonis pidana bersyarat itu untuk memberikan kesempatan kepada terpidana supaya dalam masa percobaan itu ia dapat memperbaiki diri dan tidak melakukan tindak pidana atau melanggar perjanijian yang telah diadakan, dengan harapan apabila berhasil hukuman yang telah dijatuhkan kepada terpidana itu tidak perlu dijalani selama-lamanya.

Hakim mempunyai wewenang untuk dapat menjatuhkan pidana bersyarat itu dalam hal terpidana melakukan suatu tindak pidana dan oleh hakim dijatuhi pidana yang berupa pidana penjara yang selamalamanya satu tahun atau pidana kurungan yang bukan pengganti denda. Mengenai ketentuan ini Roeslan Saleh berpendapat:

Menurut Undang-undang dapat disimpulkan bahwa pidana bersyarat dapat dijatuhkan pada pidana penjara hanyalah apabila hakim tidak ingin menjatuhkan pidana lebih dari satu tahun. Jadi yang menentukannya bukanlah pidana yang diancam atas delik yang dilakukan, tetapi pidana yang dijatuhkan kepada si terdakwa. Apabila hakim berpendapat bahwa perbuatan pidana yang dilakukan itu terlalu berat, maka sebenarnya pidana bersyarat itu tidak mungkin. ${ }^{24}$

Mengenai pidana kurungan tidak diadakan seperti halnya pidana penjara, hal ini memang tidak perlu, karena batas pidana kurungan adalah satu tahun, sedangkan untuk pidana denda dimungkinkan bersyarat jika benar-benar menurut keyakinan hakim pembayaran denda itu betul-betul dirasakan berat oleh terpidana.

\section{Hubungan Pidana Bersyarat dengan Tujuan Pemidanaan di Indonesia}

\section{Pidana Bersyarat menurut Pasal 14 a KUHP}

\footnotetext{
${ }^{23}$ Muladi, Lembaga Pidana Bersyarat (Bandung: Alumni, 1992), 195-196.

${ }^{24}$ Roeslan Saleh, Stelsel Pidana Indonesia (Jakarta: Aksara Baru, 1983), 34.
} 
Kitab Undang-Undang Hukum Pidana merupakan buah hasil dari aliran klasik, yang berpijak pada tiga tiang yakni (a) asas legalitas yang menyatakan (b) asas kesalahan, yang berisi bahwa orang hanya dapat dipidana untuk tindak pidana yang dilakukan dengan sengaja atau karena kealpaan. (c) asas pengimbalan (pembalasan) yang sekuler, yang berisi bahwa pidana secara kongrit tidak dikenakan dengan maksud untuk mencapai suatu hasil yang bermanfaat, melainkan setimpal dengan berat ringan perbuatan yang dilakukan. ${ }^{25}$

Ketentuan-ketentuan yang mengatur pidana bersyarat di dalam Pasal-pasal 14a-14f Kitab Undang-Undang Hukum Pidana itu telah ditambahkan kedalam KUHP dengan staatsblad tahun 1926 nomor 251 jo. Nomor 486 dan mulai diberlakukan di Indonesia pada tanggal 1 januari 1927. Pidana bersyarat itu telah dua belas tahun lebih dimasukan kedalam Wetboek Van straftrecht di negeri belanda, yakni dengan staatsblad tahun 1915 nomor $427 .^{26}$

Di dalam rencana undang-undang, yang kemudian telah menjadi undang-undang tanggal 12 Juni 1915, staatsblad tahun 1915 Nomor 427 termasuk di atas, para perencananya telah menggunakan perkataan voorwaardelijke strafopschorting yang kemudian telah dipakai di dalam undang-undang yang telah disahkan oleh parlemen. ${ }^{27}$

Pasal pertama yang mengatur pidana bersyarat di dalam Kitab Undang-undang Hukum Pidana itu adalah Pasal 14a Kitab Undangundang Hukum Pidana yang selanjutnya berbunyi sebagai berikut: ${ }^{28}$

(1) Apabila hakim menjatuhkan pidana penjara paling lama satu tahun atau kurungan, tidak termasuk kurungan pengganti, maka dalam putusannya dapat memerintahkan pula dikemudian hari ada putusan hakim yang menentukan lain, disebabkan karena terpidana melakukan suatu perbuatan pidana sebelum masa percobaan yang ditentukan dalam perintah di atas habis atau terpidana selama masa percobaan tidak memenuhi syarat khusus yang mungkin ditentukan dalam perintah itu.

(2) Kecuali dalam perkara pendapatan (penghasilan) dan gadai negara, maka hakim mempunyai kuasa itu juga, apabila dijatuhkan pidana denda, tetapi hanya jika ternyata

\footnotetext{
${ }^{25}$ Muladi, Lembaga Pidana Bersyarat, 62.

${ }^{26}$ P.A.F. Lamintang, Hukum Penitensier Indonesia, 36.

${ }^{27}$ Ibid., 65.

${ }^{28}$ Moeljatno, Kitab Undang-Undang Hukum Pidana (Jakarta: PT. Bumi Aksara, 2008), 7-8.
} 
kepadanya, bahwa bayaran denda itu atau rampasan yang diperintahkan dalam keputusan itu menimbulkan keberatan besar bagi orang yang dipidana itu.

(3) Apabila hukum tidak menentukan lain, maka perintah tentang pidana pokok, mengenai juga hukuman tambahan yang dijatuhkan.

(4) Perintah itu hanya diberikan, kalau sesudah pemeriksaan hakim yakin, bahwa dapat dilakukan pengawaan yang cukup atas hal yang menetapi syarat umum, yaitu bahwa orang yang dipidana tidak akan melakukan tindak pidana dan atas hal menetapi syarat khusus, jika sekiranya diadakan syarat itu.

(5) Dalam putusan yang memberi perintah yang tersebut dalam ayat pertama itu, diterangkan juga sebab-sebabnya atau hal ihwal yang menjadi alasan putusan itu.

Di dalam Pasal 14a Kitab-kitab Undang-Undang Hukum Pidana dinyatakan bahwa pidana bersyarat hanya dapat dijatuhkan bilamana memenuhi syarat-syarat sebagai berikut:

1. Dalam putusan yang menjatuhkan pidana penjara, asal lamanya tidak lebih dari satu tahun. Jadi dalam hal ini pidana bersyarat dapat dijatuhkan dalam hubungan dengan pidana penjara, dengan syarat hakim tidak ingin menjatuhkan pidana lebih dari satu tahun. Yang menentukan bukanlah pidana yang diancam atas tindak pidana yang dilakukan, tetapi pidana yang akan dijatuhkan pada si terdakwa.

2. Pidana bersyarat dapat dijatuhkan sehubungan dengan pidana kurungan, dengan ketentuan tidak termasuk pidana kurungan pengganti denda. Mengenai pidana kurungan ini tidak diadakan pembatasan, sebab maksimum dari pidana kurungan adalah satu tahun.

3. Dalam hal menyangkut pidana denda, maka pidana bersyarat dapat dijatuhkan, dengan batasan bahwa hakim harus yakin bahwa pembayaran denda betul-betul akan dirasakan berat oleh si terdakwa. $^{29}$

\section{Tujuan Pidana Bersyarat}

Sejak dicanangkannya sistem pemasyarakatan sebagai program pembinaan bagi nara pidana tahun 1964, pemerintah dalam hal ini

\footnotetext{
${ }^{29}$ Muladi, Lembaga Pidana Bersyarat, 63.
} 
Departemen Kehakiman terus berupaya melalui kebijaksanaannya untuk mewujudkan hal tersebut karena sistem yang satu ini memandang narapidana disamping sebagai makhluk individu juga sebagai makhluk sosial sehingga dinilai sangat cocok untuk diterapkan di negara hukum Indonesia.

Inti yang terkandung dalam sistem permasyarakatan ini yakni dengan dijatuhkannya pidana kepada seseorang, tujuan dari pemidanaan dapat tercapai disamping itu terdapat suatu kewajiban untuk melakukan pembinaan dan pendidikan kepada si terpidana selama menjalani masa pidananya, sehingga diharapkan ia mempunyai bekal dan kemampuan fisik maupun mental yang cukup untuk hidup kembali ditengah-tengah masyarakat setelah si terpidana tersebut selesai menjalani pidananya.

Sistem pemasyarakatan ini pada tahap pertama difokuskan sebagai program pembinaan kepada terpidana yang menjalani pidananya dilembaga pemasyarakatan, karena dijatuhi pidana pencabutan kemerdekaan. Hal ini berdasarkan kenyataan bahwa pidana yang satu ini mengandung banyak sekali kelemahan baik terhadap terpidana itu sendiri, maupun bagi masyarakat, sehingga perlu untuk dicarikan alternatif-alternative yang sekiranya mampu untuk menghilangkan kelemahan-kelemahan itu tanpa mengurangi arti dan tujuan dari pemberian pidana tersebut. Oleh karena itu penerapan pidana bersyarakat harus diarahkan pada manfaat-manfaat sebagai berikut:

a. Pidana bersyarat tersebut di satu pihak harus dapat meningkatkan kebebasan individu, dan di lain pihak mempertahankan tertib hukum serta memberikan perlindungan pada masyarakat secara efektif terhadap pelanggaran hukum lebih lanjut.

b. Pidana bersyarat harus dapat meningkatkan prestasi masyarakat terhadap falsafah rehabilitasi dengan cara memelihara kesinambungan hubungan antara narapidana dan masyarakat secara normal.

c. Pidana bersyarakat berusaha menghindarkan dan melemahkan akibatakibat negatif dari pidana perampasan kemerdekaan yang sering kali menghambat usaha pemasyarakatan kembali narapidana ke dalam masyarakat.

d. Pidana bersyarat mengurangi biaya-biaya yang harus dikeluarkan oleh masyarakat untuk membiayai sistem koreksi yang berdayaguna. 
e. Pidana bersyarat diharapkan dapat membatasi kerugian-kerugian dari penerapan pidana pencabutan kemerdekaan, khususnya terhadap mereka yang hidupnya tergantung kepada si pelaku tindak pidana.

f. Pidana bersyarat diharapkan dapat memenuhi tujuan pemidanaan yang bersifat integratif, dalam fungsinya sebagai sarana pencegahan (umum dan khusus), perlindungan masyarakat, memelihara solidaritas masyarakat dan pengimbangan. ${ }^{30}$

Syarat atau perjanjian terdiri dari; syarat umum yakni terpidana tidak boleh melakukan perbuatan yang dapat dipidana dalam jangka waktu yang tertentu (selama dalam masa percobaan). Jadi apabila hakim menjatuhkan pidana bersyarat, maka kepada terpidana harus diberikan syarat umum yang harus dipenuhi.

Arti sosial yang merupakan segi positip dari lembaga pidana bersyarat terletak pada syarat-syarat khusus yang berupa penggantian sebagian atau seluruh kerugian sebab akibat dari perbuatan yang telah dilakukan oleh pelaku atau dapat juga dalam bentuk lain menurut kebijaksanaan hakim asalkan mengenai tingkah laku dari terpidana, dengan catatan syarat-syarat tersebut tidak boleh mengurangi kemerdekaan beragama dan berpolitik bagi si terpidana. Manfaat lain dari syarat yang bersifat khusus ini terutama penggantian kerugian ini ternyata dapat mendukung eksistensi dari lembaga pidana bersyarat itu sebagai suatu pidana.

\section{Pidana bersyarat sebagai alternatif pemidanaan}

Sangat disadari bahwa masalah pidana adalah masalah yang sangat pribadi bagi seorang hakim, tetapi bagaimanapun usaha-usaha yang berusaha menyuguhkan bahkan masukan berkenaan dengan pidana bersyarat masih dipandang penting. Usaha pendayagunaan pidana bersyarat ini sangat penting, sehubungan dengan variabel hukum pidana yang berprikemanusiaan, yaitu hukum pidana yang bercirikan mengutamakan pencegahan, tidak hanya berorientasi kepada perbuatan tetapi juga orang yang melakukan perbuatan tindak pidana.

Namun pada prakteknya, pidana bersyarat dewasa ini tidak seperti di dalam teori, penjatuhan pidana bersyarat terhadap pelaku tindak pidana sering kali menuai protes baik oleh masyarakat menganggap

\footnotetext{
${ }^{30}$ Ibid., 197.
} 
penjatuhan pidana bersyarat sama saja dengan hakim memberikan putusan bebas, karena terpidana berkeliaran.

Menurut teori, pengawasan terhadap pelaksanaan pidana bersyarat dilakukan oleh yang melaksanakan eksekusi yaitu seorang jaksa. Namun dalam prateknya pengawasan oleh jaksa ini tidak berjalan semestinya. Seakan-akan pengawasan hanya bersifat formalis belaka. Dalam organisasi kejaksanaan negeri sendiri tidak ada bagian yang khusus menangani pidana bersyarat yang sangat penting ini. Setelah perjanjian antara terpidana dan jaksa seakan-akan masalah telah selesai. ${ }^{31}$

Jika peradilan kehilangan kewibawaan dan putusannya tidak lagi dihormati, maka tidak ada seorangpun yang dapat menyelesaikan masalah-masalah yang merusak tatanan sosial. Peradilan adalah klep keamanan, tanpa hal itu tidak ada masyarakat demokratis yang dapat bertahan hidup. ${ }^{32}$

Oleh karena itu salah satu cara menjaga kewibawaan hukum adalah dengan melaksanakan hukum secara adil, supaya hukum dipercaya dan dihormati dalam masyarakat.

Sangatlah tidak adil jika penjatuhan pidana bersyarat ini dijatuhkan pada delik-delik kekerasan, misalnya: pembunuhan, penganiayaan berat, perampokan, dan lain-lain. Pidana bersyarat rasanya akan lebih mencapai sasaran dan terasa adil jika dijatuhkan hanya terhadap delik tanpa korban.

Namun yang menjadi permasalahan adalah terpidana merasa jera dengan dijatuhi pidana bersyarat, dan tidak akan mengulangi perbuatannya setelah masa percobaan hukumannya selesai, karena pada masa percobaannya terpidana tetap dapat berkeliaran, lalu dimanakah letak tujuan pemidanaan itu sendiri, di mana dalam teorinya selalu dikatakan tujuandari pemidanaan itu adalah membuat pelaku menjadi jera dan memuaskan pihak yang dirugikan, baik masyarakat atau pihak yang menjadi korban. ${ }^{33}$

\section{Keuntungan Pidana Bersyarat}

Beberapa keuntungan pidana bersyarat yaitu:

\footnotetext{
${ }^{31}$ Andi Hamzah, Asas-Asas Hukum Pidana (Jakarta: Rineka Cipta, 1994), 85.

${ }^{32}$ Muhari Agus Santoso, Paradigma Baru Hukum Pidana, Cetakan 1 (Yogyakarta: Averroes Press, 2002), 3.

${ }^{33}$ Ibid., 4.
} 
1. Memberikan kesempatan kepada terpidana untuk melanjutkan hidupnya sehari-hari sebagai manusia sesuai nilai-nilai yang ada dalam masyarakat.

2. Memberikan kesempatan kepada narapidana untuk memperbaiki dirinya di dalam masyarakat.

3. Mencegah terjadinya stigma.

4. Memberikan kesempatan kepada narapidana untuk berpartisipasi dalam pekerjaan yang secara ekonomis menguntungkan masyarakat dan keluarganya.

5. Biaya lebih murah dari pada perampasan kemerdekaan.

6. Pemanfaatan fasilitas yang ada dalam masyarakat untuk mengadakan rehabilitas narapidana dan

7. Tentunya narapidana bersyarat dapat memenuhi pemidanaan yang bersifat integratif sebagai penegahan (khusus/umum) perlindungan masyarakat, pemeliharaan solidaritas dan pengimbalannya.

Lembaga pidana bersyarat dapat diefektifkan apabila hambatanhambatan dalam pelaksanaan pidana bersyarat dapat diatasi.

1. Sistem pengawasan dan pembinaan.

Hambatan dalam sistem pengawasan pembinaan:

a) Belum melembaganya pola-pola pengawasan yang dilakukan dan sistem dalam pengawasan.

b) Pasal 280 ayat (4) KUHP yang mengatur peranan hakim pengawas dan pengaturan di dalam pelaksanaan pidana bersyarat belum berfungsi sebagaimana mestinya terhubung, belum adanya pengaturan pelaksanaan Pasal tersebut di atas.

2. Perundang-undangan.

Hambatan dalam sistem perundang-undangan:

a) Belum adanya pedoman yang jelas tentang penerapan pidana bersyaratyang menyangkut hakekat, tujuan yang hendak dicapai, serta-serta ukuran-ukuran di dalam menjatuhkan pidana bersyarat.

b) Tidak adanya pedoman penerapan pidana bersyarat tersebut menyebabkan timbulnya pertimbangan-pertimbangan yang mendasar atas subyektifitas hakim di dalam mengadili suatu perkara.

3. Teknik dan Administrasi

Hambatan dalam sistem tekink dan administrasi:

a) Terpidana tidak boleh di rumah 
b) Terpidana berdomisili dipelosok yang tidak terjangkau

c) Terpidana secara diam-diam pindah tempat tinggal

4. Sarana dan prasarana

Hambatan dalam sistem sarana dan prasarana:

a) Kurangnya sarana angkutan untuk tugas pengawasan

b) Petugas-petugas jumlahnya terbatas

c) Anggaran perjalanan untuk dinas pengawasan jumlahnya terbatas.

5. Proses penjatuhan pidana

Hambatan dalam sistem penjatuhan pidana:

a) Jaksa maupun hakim sangat selektif dan membatasi diri di dalam menuntut atau menjatuhi sanksi pidana bersyarat

b) Terpidana tidak boleh memperoleh petukan vonis hakim, sehingga tidak mengetahui secara jelas pertimbangan hakim

c) Hakim tidak memperoleh laporan pemeriksaan pribadi pelaku tindak pidana yang sangat penting sebagai bahan untuk memutuskan pidana secara cepat

d) Pedoman penjatuhan pidana bersyarat tidak hanya menyangkut hal-hal yang bersifat obyektif (yang menyangkut perbuatannya), tetapi juga menyangkut hal-hal yang bersifat subyektif (menyangkut si pembuat ).

\section{Pidana Bersyarat menurut Hukum di Indonesia}

Pidana bersyarat diberlakukan di Indonesia pada tanggal 1 januari 1927 dengan staatblad 1926 No. 251 jo. 486, pada bulan Januari 1927 yang kemudian diubah dengan staatblad No. $172 .{ }^{34}$ Pidana bersyarat sendiri memiliki sinonim dengan hukuman percobaan (Voorwardelojke Veroordeling). Namun berkaitan dengan penamaan ini juga ada yang mengatakan kurang sesuai sebab dengan penamaan itu memberi kesan seolah-olah yang digantungkan pada syarat itu adalah pemidanaanya atau penjatuhan pidananya. Padahal yang digantungkan pada syarat-syarat tertentu itu, sebenarnya adalah pelaksanaan atau eksekusi dari pidana yang telah dijatuhkan oleh hakim. Oleh karena itu, terdapat beberapa pendapat yang dikemukakan para ahli hukum dalam mendefinisikan pidana bersyarat itu sendiri, antara lain:

Muladi menyatakan: ${ }^{35}$

${ }^{34}$ Muladi, Lembaga Pidana Bersyarat, 63.

${ }^{35}$ Ibid., 195-196. 
Pidana bersyarat sebagai suatu pidana, dalam hal mana si terpidana tidak usah menjalani pidana tersebut, kecuali bilamana selama masa percobaan si terpidana telah melanggar syarat-syarat umum dan khusus yang telah ditentukan oleh pengadilan.

P.A.F Lamintang menyatakan: ${ }^{36}$

"pidana bersyarat adalah suatu pemidanaan yang pelaksanaannya oleh hakim telah digantungkan pada syarat-syarat tertentu yang diterapkan dalam putusannya"

Selanjutnya R. Soesilo menyatakan: ${ }^{37}$

Pidana bersyarat yang biasa disebut peraturan-peraturan tentang "hukuman dengan perjanjian" atau "hukuman dengan bersyarat" atau "hukuman jenggalan", artinya adalah: orang dijatuhi hukuman. Tetapi hukuman itu tidak usah dijalankan, kecuali jika dikemudian ternyata bahwa terhukum sebelum habis tempo percobaan berbuat peristiwa pidana atau melanggar perjanjian yang diadakan oleh hakim kepadanya jadi keputusan hakim tetap ada.

Selain mengenai pengertian pidana bersyarat di atas, R. Soesilo juga berpendapat bahwa maksud dari penjatuhan pidana bersyarat ini adalah untuk memberi kesempatan kepada terpidana supaya dalam tempo percobaan itu ia memperbaiki dirinya dengan jalan menahan diri tidak akan berbuat tindak pidana lagi atau melanggar perjanjian (syaratsyarat) yang telah ditentukan oleh hakim kepadanya. ${ }^{38}$

Melihat pendapat para ahli di atas bisa dikatakan bahwa pidana bersyarat sebagai upaya menjauhi proses pemidanaan yang monoton (penjara), dalam artian selalu berujung ke penjara. Yang ditekankan disini adalah bagaimana memperdayakan pelaku tindak pidana yang masih bisa diperbaiki, dimana tidak langsung dirampas kemerdekaannya. Oleh sebab itu, maka yang perlu diperhatikan juga tentunya ialah kehatihatian hakim dalam menjatuhkan pidana bersyarat ini, maksudnya dalam menerapkan pidan bersyara hakim harus sangat selektif untuk menerapkannya.

Pengaturan mengenai pidana bersyarat ini sendiri di dalam KUHP terdapat pada:

Pasal 14 a ayat (1):

\footnotetext{
${ }^{36}$ P.A.F. Lamintang, Hukum Penitensier Indonesia, 136.

${ }^{37}$ R. Soesilo, Pokok-pokok Hukum Pidana, 53.

38 Ibid., 54.
} 
Apabila hakim menjatuhkan pidana penjara paling lama satu tahun atau kurungan, tidak termasuk kurungan pengganti, maka dalam putusannya dapat memerintahkan pula dikemudian hari ada putusan hakim yang menentukan lain, disebabkan karena terpidana melakukan suatu perbuatan pidana sebelum masa percobaan yang ditentukan dalam perintah di atas habis atau terpidana selama masa percobaan tidak memenuhi syarat khusus yang mungkin ditentukan dalam perintah itu.

\section{Pasal 14b KUHP}

1) Dalam perkara kejahatan dan pelanggara yang diterangkan dalam Pasal 492, 504, 505, 506 dan 536, maka percobaan itu selama-lamanya tiga tahun dan perkara pelanggaran yang lain selama-lamanya dua tahun.

2) Masa percobaan itu mulai, segera putusan itu sudah menjadi tetap dan diberitahukan kepada orang yang dipidana menurut cara yang diperintahkan dalam undang-undang.

3) Masa percobaan itu tidak dihitung, selama orang yang dipidana ditahan dengan sah.

Pasal 14c ayat (1) KUHP merumuskan sebagai berikut:

1) Dengan perintah yang dimaksud pasal 14a, kecuali jika dijatuhkan pidana denda, selain menetapkan syarat umum bahwa terpidana tidak akan melakukan tindak pidana, hakim dapat menetapkan syarat khusus bahwa terpidana dalam waktu tertentu, yang lebih pendek dari pada masa percobaannya, harus mengganti segala atau sebagian kerugian yang ditimbulkan oleh tindak pidana, semuanya atau sebagiannya saja, yang akan ditentukan pada perintah itu dalam waktu yang akan ditentukan pada perintah itu juga, yang kurang dari pada masa percobaan itu.

(2) Dalam hal menjatuhkan pidana, baik pidana penjara yang lamanya lebih dari tiga bulan, maupun pidana kurungan karena salah satu pelanggaran yang diterangkan dalam pasal 492, 504, 505, 506 dan 536, maka pada perintahnya itu hakim boleh mengadakan syarat khusus yang lain pula tentang kelakuan orang yang dipidana itu, yang harus dicukupinya dalam masa percobaan itu atau dalam sebagian masa itu yang akan ditentukan pada perintah itu.

(3) Segala janji itu tidak boleh mengurangkan kemerdekaan agama atau kemerdekaan politik.

Pasal 14d KUHP 
(1) Pengawasan atas hal yang mencukupi tidaknya segala janji itu diserahkan kepada pegawai negeri yang akan menyuruh menjalankan pidana itu,jika sekiranya kemudian hari diperintahkan akan menjalankannya.

(2) Jika dirasanya beralasan, maka dalam perintahnya, hakim boleh memberi perintah kepada sebuah lembaga yang bersifat badan hukum dan berkedudukan di daerah Republik Indonesia atau kepada orang yang memegang sebuah lembaga yang berkedudukan di situ atau kepada seorang pegawai neeri istimewa, supaya memberi pertolongan dan bantuan kepada orang yang dipidana itu tentang mencukupi syarat khusus itu.

\section{Pasal 14e KUHP}

Baik sesudah menerima usul dari pegawai negeri yang tersebut dalam ayat pertama pasal $14 \mathrm{~d}$, maupun atas permintaan orang yang diberi putusan mengubah syarat khusus yang ia telah tetapkan atau waktu berlaku syarat itu diadakannya dalam masa percobaan, dapat menyerahkan hal memberi bantuan itu kepada orang lain daripada yang sudah diwajibkan atau dapat memperpanjang masa percobaan itu satu kali. Tambahan itu tidak boleh lebih dari seperdua waktu yang selamalamanya dapat ditentukan untuk masa percobaan itu.

\section{Pasal 14f KUHP}

(1) Dengan tidak mengurangi ketentuan pada pasal yang di atas, maka sesudah menerima usul dari pegawai negeri yang diterangkan dalam ayat pertama pasal 14d, hakim yang mula-mulai memberi putusan dapat memerintahkan supaya putusan itu dijalankan, atau menentukan supaya orang yang dipidana itu ditegur atas namanya, yaitu jika dalam masa percobaan itu orang tersebut melakukan tindak pidana dan karena itu dipidana menurut putusan yang tak dapat diubah lagi, atau jika masa percobaan itu orang tersebut dipidana menurut putusan yang tak dapatdiubah lagi karena tindak pidana yang dilakukannya sebelum masa percobaan itu mulai. Dalam hal memberi teguran itu hakim menentukan pula caranya menegur.

(2) Perintah menjalankan pidana tidak lagi dapat diberikan, jika masa percobaan sudah habis, kecuali jika sebelum habis masa percobaan itu orang yang dipidana tersebut dituntut karena melakukan tindak pidana, dan kesudahan tuntutan itu orangnya dipidana menurut putusan yang tak dapat 
dirubah lagi. Dalam hal itu boleh juga perintah akan mejalankan pidananya diberikan dalam dua bulan sesudah putusan pidana orang itu menjadi tak dapat dirubah lagi. ${ }^{39}$

Pasal dalam KUHP tersebut di atas oleh Muladi disimpulkan menjadi persyaratan dapat dijatuhkannya pidana bersyarat yaitu antara lain: ${ }^{40}$

1. Dalam putusan yang menjatuhkan pidana penjara, asal lamanya tidak lebih dari satu tahun. Jadi dalam hal ini pidana bersyarat dapat dijatuhkan dalam hubungan dengan pidana penjara dengan syarat hakim tidak ingin menjatuhkan pidana lebih dari satu tahun, sehingga yang menentukan bukanlah pidana maksimal yang dapat dijatuhkan pada pelaku tindak pidana tersebut, tetapi pada pidana yang dijatuhkan terhadap si terdakwa. Dari penjelasan tersebut nampak bahwa pidana bersyarat dipergunakan berdasarkan maksud dari pada hakim dalam memutus, pada saat ia memberi pidana satu tahun maka hakim tersebut memiliki hak untuk memberikan pidana bersyarat pada terdakwa tersebut. Akan tetapi perlu diperhatikan bahwa dalam Pasal 14 a ayat (2) hakim dibatasi secara jelas berkaitan dengan jenis tindak pidana yang tidak dapat dijatuhkan pidana bersyarat (penyimpangan), antara lain:

1) Perkara-perkara mengenai penghasilan dan persewaan negara apabila menjatuhkan pidana denda, namun harus pula dibuktikan bahwa pidana denda dan perampasan tersebut memang memberatkan pidana;

2) Kejahatan dan pelanggaran candu, perbuatan tersebut dianggap sebagai perkara mengenai penghasilan negara;

3) Berkaitan dengan pidana denda yang dijatuhkan tidak dapat digantikan dengan pidana kurungan.

Selain ketiga hal di atas sebagai pengecualian tidak dapat dijatuhkannya pidana bersyarat, terdapat juga pengecualian lain mengenai lama waktu satu tahun juga dapat disimpangi yaitu dengan masa percobaan selama tiga tahun namun bagi kejahatan dan pelanggaran tertentu yaitu:

\footnotetext{
${ }^{39}$ Moeljatno, Kitab Undang-Undang Hukum Pidana, 7-10.

${ }^{40}$ Muladi, Lembaga Pidana Bersyarat, 88.
} 
a. Perbuatan dengan merintangi lalu lintas atau mengganggu ketertiban atau keamanan bagi orang-orang lain ataupun melakukan sesuatu, dalam hal ini tindakan tersebut dilakukan di tempat umum dan dalam keadaan mabuk. ${ }^{41}$

b. Perbuatan meminta-minta pemberian di depan umum, baik dilakukan oleh sendiri ataupun oleh tiga orang atau lebih secara bersama-sama dan umur mereka sudah lebih dari enam belas tahun. $^{42}$

c. Perbuatan berkeliaran kemana-mana tanpa memiki mata pencaharian, perbuatan tersebut dilakukan oleh sendiri ataupun oleh tiga orang atau lebih dan usia mereka di atas enam belas tahun dalam hal ini perbuatan tersebut adalah bergelandangan. ${ }^{43}$

d. Perbuatan sebagai germo dengan mengambil keuntungan dari perbuatan susila oleh seorang wanita. ${ }^{44}$

e. Perbuatan berada di jalan umum dalam keadaan mabuk. ${ }^{45}$

2. Pidana bersyarat dapat dijatuhkan sehubungan dengan pidana kurungan, dengan ketentuan tidak termasuk pidana kurungan pengganti denda, mengenai pidana kurungan tidak diadakan pembatasan, sebab dalam pasal 18 ayat (1) KUHP sudah jelas menyatakan bahwa pidana kurungan dapat dijatuhkan pada terdakwa paling lama satu tahun dan paling cepat satu hari, alasan pidana kurungan pengganti denda tidak dapat dikenakan pidana bersyarat karena pidana kurungan itu sendiri sudah menjadi syarat apabila terpidana tidak dapat membayar denda, sehingga tidak mungkin dibebankan pidana bersyarat terhadap sesuatu yang sudah menjadi syarat dari pidana pokok yang dijatuhkan.

3. Dalam hal menyangkut pidana denda, maka pidana bersyarat dapat dijatuhkan dengan batasan bahwa hakim harus yakin bahwa pembayaran denda betul-betul akan dirasakan berat oleh si terdakwa.

Pada penjatuhan pidana bersyarat, harus mencantumkan alasanalasan yang dijadikan dasar pertimbangan oleh hakim terhadap putusan yang dijatuhkan kepada terpidana. Dan alasan-alasan tersebut juga harus disertai oleh syarat-syarat. Di dalam pidana bersyarat terdapat "syarat

\footnotetext{
41 Pasal 492 KUHP.

42 Pasal 504 KUHP

43 Pasal 505 KUHP

44 Pasal 506 KUHP

45 Pasal 536 KUHP
} 
umum dan syarat khusus". Syarat umum adalah bahwa terpidana tidak boleh melakukan suatu tindak pidana atau yang sifatnya melanggar hukum selama masa percobaanyang telah ditentukan oleh hakim. Syarat khusus yang mengatakan bahwa harus mengganti kerugian yang timbul sebagai akibat dari perbuatan yang sifatnya melanggar hukum, baik seluruhnya ataupun sebagian dari kerugian yang telah ditetapkan di dalam perintah penangguhan pelaksanaan pidana. ${ }^{46}$

Di dalam syarat-syarat khusus tersebut, hakim mempunyai kebebasan untuk menetapkan syarat-syarat yang harus dipenuhi oleh terpidana. Akan tetapi syarat-syarat tersebut tidak boleh menghalangi terpidana untuk beragama dan tidak boleh membatasi terpidana melakukan kegiatan yang sah menurut ketatanegaraan (Pasal 14c ayat (3) KUHP).

Beberapa hal yang dikemukakan di atas adalah menyangkut persyaratan dapat dan tidak dapatnya dijatuhkan pidana bersyarat. Selain itu juga perlu diketahui bahwa masa percobaan yang berkaitan dengan pidana bersyarat tersebut mulai dihitung dan berlaku sejak putusan hakim itu sudah mempunyai kekuatan hukum tetap dan pasti (pasal 14b ayat (2)), selain itu keputusan hakim itu sendiri telah diberitahukan kepada terpidaan sesuai dengan tata aturan hukum yang sah, apabila kita mengacu pada Staatblad tahun 1926 Nomor 251 jo 486 mengenai aturan pidana bersyarat (regeling van de voorwaardelijke veroordeling) itu sendiri bahwa dalam pasal 1 menyatakan: ${ }^{47}$

"ditentukan putusan pengadilan yang berisi tentang perintah pidana bersyarat setelah mempunyai kekuatan hukum yang tetap, oleh pejabat yang berwenang untuk melaksanakan putusan pengadilan, secepat mungkin harus diberitahukan kepada terpidana secara pribadi dan menjelaskan mengenai isi dari putusan tersebut, dengan menyerahkan suatu pemberitahuan mengenai pidana yang telah dijatuhkan kepadanya dan mengenai semua isi keputusan yang berkenaan dengan perintah tersebut."

Selain syarat normatif yang diatur dalam KUHP, hakim juga perlu mempertimbangkan pendapat Muladi, yang memberikan persyaratan

\footnotetext{
${ }^{46}$ P.A.F. Lamintang, Hukum Penitensier Indonesia, 154.

47 Ibid., 157.
} 
tambahan untuk dapat dijatuhkannya pidana bersyarat terhadap pelaku tindak pidana yang terbukti berbuat, antara lain: ${ }^{48}$

a. Sebelum melakukan tindak pidana itu, terdakwa belum pernah melakukan tindak pidana lain dan selalu taat pada hukum yang berlaku.

b. Terdakwa masih sangat muda (12-18 tahun).

c. Tindak pidana yang dilakukan tidak menimbulkan kerugian yang terlalu besar.

d. Terdakwa tidak menduga, bahwa tindak pidana yang dilakukannya akan menimbulkan kerugian yang besar.

e. Terdakwa melakukan tindak pidana disebabkan adanya hasutan orang lain yang dilakukan dengan intensitas yang besar.

f. Terdapat alasan-alasan yang cukup kuat, yang cenderung untuk dapat dijadikan dasar memaafkan perbuatannya.

g. Korban tindak pidana mendorong terjadinya tindak pidana tersebut.

h. Terdakwa telah membayar ganti rugi atau akan membayar ganti rugi kepada si korban atas kerugian-kerugian atau penderitaan penderitaan akibat perbuatannya.

i. Tindak pidaan tersebut merupakan akibat dari keadaan-keadaan yang tidak mungkin terulang lagi.

j. Kepribadian dan perilaku terdakwa meyakinkan bahwa ia tidak akan melakukan tindak pidana yang lain.

k. Pidana perampasan kemerdekaan akan menimbulkan penderitaan yang besar, baik terhadap terdakwa maupun terhadap keluarganya.

1. Terdakwa diperkirakan dapat menanggapi dengan baik pembinaan yang bersifat non-institusional.

m. Tindak pidana terjadi di kalangan keluarga.

n. Tindak pidana terjadi karena kealpaan.

o. Terdakwa sudah sangat tua.

p. Terdakwa adalah pelajar atau mahasiswa.

q. Khusus untuk terdakwa di bawah umur, hakim kurang yakin akan kemampuan orang tua untuk mendidik.

Berkaitan dengan pelaku yang dikenai pidana bersyarat, apabila dalam proses pemeriksaan terpidana bersyarat dikenai penahanan (perampasan kemerdekaan), maka masa percobaan terhadap terpidana tersebut tidak berlaku pada saat selama terpidana tersebut

\footnotetext{
${ }^{48}$ Muladi, Lembaga Pidana Bersyarat, 198-200.
} 
dirampas kemerdekaannya. ${ }^{49}$ Bagi pelaku tindak pidana yang dijatuhi pidana bersyarat, hakim dapat memberikan syarat- syarat khusus, selain dari pada syarat umum yang telah disebutkan di atas, syarat khusus yang dapat dijatuhkan hakim khusus yang dapat dijatuhkan hakim tersebut seperti pembebanan ganti kerugian terhadap korban berkaitan dengan akibat yang timbul dari perbuatan pelaku yang telah melanggar hukum, pembebanan ganti kerugian tersebut menyangkut sebagian ataupun seluruh kegiatan yang ditimbulkan, ${ }^{50}$ akan tetapi persyaratan khusus yang dapat dijatuhkan oleh hakim tersebut tidak boleh membatasi kemerdekaan terpidana untuk beragama dan kebebasannya menurut ketatanegaraan.

Seseorang yang dikenai pidana bersyarat apabila melakukan perbuatan yang dapat dihukum dan hukuman yang diterimanya sudah mempunyai kekuatan hukum tetap, ataupun jika si terpidana tidak mentaati serta melanggar syarat khusus yang telah dijatuhkan kepadanya, maka hakim yang mejatuhkan pidana bersyarat tersebut dapat memerintahkan agar hukuman sebagai konsekuensi pidana bersyarat tersebut dilaksanakan atau memberi peringatan terhukum atas perbuatan yang telah dilakukannya.

Pidana bersyarat berlaku sehubungan pidana pokok yang dijatuhkan oleh hakim terhadap pelaku tindak pidananya sendiri adalah pidana penjara, namun dengan pertimbangan tertentu, maka hakim memberikan kesempatan kepada terpidana untuk tidak perlu menjalani pidana penjara tersebut. Sebab hakim dalam menjatuhkan pidana bersyarat ini berpendapat terpidana masih memiliki kesempatan dan mau untuk berubah terpidana untuk memperbaiki diri, dan terpidana tidak dipisahkan keberadaannya dari masyarakat, hal ini sama dengan pendapat Roeslan Saleh, yaitu:

"Janganlah jatuhkan pidana penjara atau pidana kurungan yang tidak bersyarat, jika suatu pidana bersyarat dipandang telah cukup. Janganlah jatuhkan pidana perampasan kemerdekaan yang sifatnya adalah panjang, jika suatu pidana waktunya pendek telah menyelesaikan persoalan itu." ${ }^{.51}$

\footnotetext{
${ }^{49}$ Pasal 14 b ayat (3) KUHP

${ }^{50}$ Pasal $14 \mathrm{c}$ ayat (1) KUHP

${ }^{51}$ Roeslan Salah, dari Lembaga Kepustakaan Hukum Pidana, 50.
} 
Berdasarkan pengertian serta pengaturan pidana bersyarat di atas, maka Muladi memberikan pendapat mengenai manfaat-manfaat dari pidana bersyarat tersebut antara lain: ${ }^{52}$

a. Pidana bersyarat tersebut di satu pihak harus dapat meningkatkan kebebasan individu dan di lain pihak mempertahankan tertib hukum serta memberikan perlindungan kepada masyarakat secara efektif terhadap pelanggaran hukum lebih lanjut

b. Pidana bersyarat harus dapat meningkatkan persepsi masyarakat terhadap falsafah rehabilitasi dengan cara memelihara kesinambungan hubungan antara narapidana dengan masyarakat secara normal

c. Pidana bersyarat berusaha menghindarkan dan melemahkan akibat-akibat negatif dari pidana perampasan kemerdekaan yang seringkali menghambat usaha pemasyarakatan kembali narapidana ke dalam masyarakat

d. Pidana bersyarat mengurangi biaya-biaya yang harus dikeluarkan oleh masyarakat untuk membiaya sistem koreksi yang berdaya guna

e. Pidana bersyarat diharapkan dapat membatasi kerugian-kerugian dari penerapan pidana pencabutan kemerdekaan, khususnya terhadap mereka yang kehidupannya tergantung kepada si pelaku tindak pidana

f. Pidana bersyarat diharapkan dapat memenuhi tujuan pemidanaan yang bersifat integratif, dalam fungsinya sebagai sarana pencegahan (umum dan khusus), perlindungan masyarakat, memelihara solidaritas masyarakat dan pengimbalan.

\section{Analisis Pidana Bersyarat menurut Hukum Pidana Islam}

Dalam Hukum Pidana Islam secara umum, tidak ditemukan sebuah istilah yang mengandung makna "pidana bersyarat" secara menyeluruh. Namun demikian, berdasarkan ciri-ciri yang dapat dikategorikan pidana bersyarat dalam hukum pidana Indonesia, terdapat beberapa klasifikasi yang serupa dengan pidana bersyarat dalam hukum pidana Islam, antara lain:

1. Bahwa, pidana bersyarat merupakan salah satu jenis pidana yang termasuk dalam sistem pemidanaan;

\footnotetext{
${ }^{52}$ Muladi, Lembaga Pidana Bersyarat, 197.
} 
2. Bahwa di dalam pidana bersyarat, pidana pokok awal tidak dijalankan karena sebab tertentu. Akan tetapi, timbul pidana pokok $^{53}$ lain dengan disertai syarat-syarat di dalamnya;

3. Bahwa, tidak dihilangkannya maksud dan tujuan dari pemidanaan itu sendiri (efek jera dan pendidikan).

Berdasarkan klasifikasi tentang pidana bersyarat di atas, dapat menunjukkan kedekatan proses pemidanaan ini dengan jenis pidana dalam hukum pidana Islam, diantaranya yaitu:

\section{Diyât}

Diyât merupakan suatu jenis pidana yang memberikan sejumlah harta dalam ukuran tertentu, yang diberikan pelaku tindak pidana kepada korban atau ahli warisnya. ${ }^{54}$

Merujuk definisi di atas, maka diyât merupakan pidana yang mempunyai satu batasan. Artinya, hakim tidak berhak mengurangi atau menambahi jumlahnya. Jadi diyât merupakan pidana ganti rugi dari pelaku kepada korban (murni diterima oleh pihak korban).

Pada dasarnya hukum pidana Islam menetapkan dua bentuk pidana atas tindak pidana pembunuhan dan pelukaan, yaitu qisâs dan diyât. Qisâs merupakan pidana pokok pada tindak pidana tersebut di atas, dimana pidana qisâs ini merupakan jenis pidana yang menghukum pelakunya seperti apa yang telah dilakukannya terhadap korban.

Akan tetapi yang menjadi kelebihan dari pidana ini adalah, adanya hak perorangan di dalamnya. Maksudnya, bahwa korban atau walinya diberi wewenang untuk pemaafan atas pidana qisâs. Apbila korban atau walinya memaafkan, maka gugurlah pidana qisâs tersebut. Pemberian pemaafan terkadang bisa dengan cuma-cuma dan pidana diyât pun menjadi batal (gugur). Yang perlu ditekankan disini adalah, bahwa batalnya piadana qisâs tidak serta-merta pelaku bebas begitu saja. Dimana hakim ataupun penguasa dapat mengalihkan dengan bentuk pemidanaan yang lain dengan melihat diri dan kondisi korban.

Dasar hukum dari diyât itu sendiri tersirat di dalam firman Allah swt dalam surat An-Nisa' ayat 92:

"Dan tidak layak bagi seorang mukmin membunuh seorang mukmin (yang lain), kecuali karena tersalah (tidak sengaja), dan

Barangsiapa membunuh seorang mukmin karena tersalah

\footnotetext{
${ }^{53}$ Pidana pokok disisni di artikan sebagai pidana yang harus dijalankan, walaupun jenisnya sebagai pidana pengganti dari pidana pokok yang sebenarnya.

${ }^{54}$ Alie Yafi, dkk, Ensiklopedi Hukum Pidana Islam, 71.
} 
(hendaklah) ia memerdekakan seorang hamba sahaya yang beriman serta membayar diyât yang diserahkan kepada keluarganya (si terbunuh itu), kecuali jika mereka (keluarga terbunuh) bersedekah. jika ia (si terbunuh) dari kaum (kafir) yang ada Perjanjian (damai) antara mereka dengan kamu, Maka (hendaklah si pembunuh) membayar diyât yang diserahkan kepada keluarganya (si terbunuh) serta memerdekakan hamba sahaya yang beriman. Barangsiapa yang tidak memperolehnya, Maka hendaklah ia (si pembunuh) berpuasa dua bulan berturutturut untuk penerimaan taubat dari pada Allah. dan adalah Allah Maha mengetahui lagi Maha Bijaksana.” (QS. An- Nisa: 92) ${ }^{55}$

Dan juga terdapat di dalam surat al-Baqarah ayat 178 :

"Hai orang-orang yang beriman, diwajibkan atas kamu qishaash berkenaan dengan orang-orang yang dibunuh; orang merdeka dengan orang merdeka, hamba dengan hamba, dan wanita dengan wanita. Maka Barangsiapa yang mendapat suatu pema'afan dari saudaranya, hendaklah (yang mema'afkan) mengikuti dengan cara yang baik, dan hendaklah (yang diberi ma'af) membayar (diyât) kepada yang memberi ma'af dengan cara yang baik (pula). Yang demikian itu adalah suatu keringanan dari Tuhan kamu dan suatu rahmat. Barangsiapa yang melampaui batas sesudah itu, maka baginya siksa yang sangat pedih." ${ }^{\text {"Q }}$ (QS. Al-Baqarah:178) $)^{57}$

Serta hadis Rasulullah Saw:

"Dari Abi Syuraih Al-Khuza'i berkata: Telah bersabda Rasulullah Saw: Maka barang siapa yang salah seorang anggota keluarganya menjadi korban pembunuhan setelah ucapanku ini, keluarganya memiliki dua pilihan adakalanya memilih diyât, atau memilih qisâs" (Hadis ini dikeluarkan oleh Abu Dawud dan Nasa'i) ${ }^{58}$

Seiring penjelasan di atas bisa dipahami bahwa, hukum pidana Islam tidak sekeras dan sekaku yang dibayangkan. Di mana pada dasarnya, pidana kisas dan diyât bertujuan untuk menjaga kemaslahatan

\footnotetext{
${ }^{55}$ Departemen Agama RI, al-Qur'an dan Terjemahannya, 135.

56 Qisâs ialah mengambil pembalasan yang sama. qishaash itu tidak dilakukan, bila yang membunuh mendapat kema'afan dari ahli waris yang terbunuh yaitu dengan membayar diat (ganti rugi) yang wajar. pembayaran diat diminta dengan baik, umpamanya dengan tidak mendesak yang membunuh, dan yang membunuh hendaklah membayarnya dengan baik, umpamanya tidak menangguh-nangguhkannya. bila ahli waris si korban sesudah Tuhan menjelaskan hukum-hukum ini, membunuh yang bukan si pembunuh, atau membunuh si pembunuh setelah menerima diat, maka terhadapnya di dunia diambil qisâs dan di akhirat dia mendapat siksa yang pedih.

${ }^{57}$ Departemen Agama RI, al-Quran dan Terjemahannya 43.

${ }^{58}$ Abu Dawud bin Sulaiman Syajastani, Sunan Abi Dawud (Lebanon: Darul Fiqri, 1993), Juz 4, 17.
} 
masyarakat. Suatu pidana dijatuhkan atau diterapkan untuk memberantas dan mencegah terjadinya tindak pidana serta sebagai alat untuk menjaga keamanan dan ketentraman masyarakat. Jadi, ketika pidana qisâs gugur karena sebab yang diperbolehkan dengan shar'i, maka diyât timbul menjadi pidana pokok bukan sebagai pidana pengganti.

Yang paling menarik menurut penulis, adalah keunggulan dari konsep pemidanaannya. Dimana hukum pidana Islam memberikan hak pengampunan (pemaafan) kepada korban atau walinya sebagai hak absolut, yang tentunya berdasarkan pertimbangan logis dan praktis. Pertimbangan logis disini memaknai, bahwa pemaafan diharapkan menghilangkan kedengkian dan pertikaian diantara keduanya. Artinya, ada sisi-sisi positif yang dapat merubah pribadi masing-masing baik itu korban ataupun pelaku itu sendiri. Sedangkan pertimbangan praktis, diartikan sebagai proses pengalihan bentuk pidana yang kearah yang lebih baik disertai sikap toleransi, memaafkan dan melemahkan rasa permusuhan. Yang tentunya tidak melepas tanggungjawab si pelaku, yaitu membayar diyât sebagai proses pemaafan. Hal tesebut dapat dilakukan karena diperbolehkan oleh syariat. ${ }^{59}$

Secara umum memang semua diyât adalah seratus ekor unta. Adapun berat-ringannya hukuman diyât bukan pada bilangannya, melainkan hanya pada macam dan umur unta. Telah diketahui bahwa, ada diyât yang diperberat dan diyât yang diperingan. Diyât diperberat disebut sebagai diyât Mughalladzah, jenis diyât ini diperlakukan pada tindak pidana pembunuhan sengaja dan menyerupai sengaja, itupun setelah ada pemaafan dari korban atau walinya. Pemberatan diyât Mughalladzah ini dapat dilihat dari tiga aspek, yaitu:

1. Pembayaran ditanggung sepenuhnya oleh pelaku;

2. Pembayaran harus tunai (tidak boleh dicicil); serta,

3. Umur unta lebih dewasa. Misalnya menurut Syafi'iyah unta harus berumur tiga tahun keatas, bahkan sebagian harus dalam keadaan bunting. ${ }^{60}$

Sedangkan, diyât Mukhaffafah (diyât yang diperingan), keringanan dalam diyât ini dalam dilihat dengan tiga aspek, yaitu:

1. Kewajiban pembayaran dibebankan kepada aqilah (keluarga);

2. Pembayaran dapat diangsur tiga tahun;

\footnotetext{
${ }^{59}$ Alie Yafie, dkk., Ensiklopedi Hukum Pidana Islam, 71.

${ }^{60}$ Ahmad Wardi Muslich, Hukum Pidana Islam, 171.
} 
3. Komposisi diyât dibagi menjadi lima kelompok:

a. 20 ekor unta bintu makhadh (unta betina umur 1-2 tahun),

b. 20 ekor unta ibnu makhadh (unta jantan umur 1-2 tahun),

c. 20 ekor unta bintu labun (unta betina umur 2-3 tahun),

d. 20 ekor unta hiqqah (umur 3-4 tahun),

e. 20 ekor unta jadza'ah (umur 4-5 tahun). ${ }^{61}$

Kedua diyât tersebut di atas dapat dikatakan sebagai diyât lengkap (ad-diyât al-Kâmilah). Sedangkan, ada yang dinamakan diyât tidak lengkap yaitu Arsy. Ada dua jenis diyât arsy. Pertama, arsy yang telah ditentuka ukurannya oleh shar'i, seperti; arsy jari dan arsy tangan. Yang kedua adalah, arsy yang belum ada ketetapan nasnya sehingga hakim diberikan wewenang untuk ukurannya.

\section{Ta'zîr}

Ta'zîr merupakan jenis pidana terhadap jarîmah-jarîmah yang hukumannya belum ditetapkan oleh shara'(al-Qur'an dan hadis). Maka, pidana ta'zîr adalah sekumpulan pidana yang belum ditentukan jumlahnya. Yang dimulai dari pidana yang paling ringan, seperti; nasihat dan teguran, sampai kepada hukuman yang paling berat, seperti; kurungan dan dera, bahkan sampai kepada hukuman mati dalam tindak pidana yang berbahaya. ${ }^{6}$

Adapun tindak pidana yang diancamkan pidana ta'zîr adalah setiap tindak pidana selain pidana hudûd, qisâs, dan diyât. Karena ketiga tindak pidana tersebut memiliki jenis pidana yang telah ditentukan bentuk dan jumlahnya oleh shara'. Ketika pidana ta'zîr dijatuhkan atas ketiga tindak pidana tadi, maka pidana ta'zîr bukan sebagai pidana pokok melainkan pidana pengganti. Hal ini dapat terjadi ketika terhalangnya pidana hudûd yang dikarenakan, tidak sempurnanya syarat untuk melaksanakan pidana hudûd, atau pidana tambahan yang ditambahkan untuk hukuman pokok, untuk pengasingan untuk tindak pidana zina (setelah hukuman dera) menurut Imam Abu Hanifah, atau pidana ta'zîr yang ditambahkan dalam pidana qisâs pada tindak pidana pelukaan, menurut Imam Abu Hanifah, atau tambahan empat puluh kali dera bagi peminum minuman keras, menurut Imam Syafi'i.

\footnotetext{
61 lbid., 171.

62 Ibid., 84.
} 
Di dalam ta'zîr ini hakim mempunyai wewenang yang cukup luas untuk memilih jenis pidana yang sesuai dengan keadaan tindak pidana serta diri pelakunya. Kelonggaran atau kemudahan yang diberikan kepada hakim tidak mengurangi tujuan awal dalam setiap pemidanaan, sebagai wujud memperbaiki diri pelaku demi terjaganya kemaslahatan di dalam masyarakat.

Yang perlu ditekankan di sini adalah sifat dari pidana ta'zîr itu sendiri. Di mana ciri khanya terletak pada keleluasaan hakim untuk memilih diantara sekumpulan pidana lain. Ini menimbulkan sisi positfp dalam penjatuhkan pidana, ketika hakim menurut pandangannya dapat mempertimbangkan diri si pelaku serta keadaanya akan sebuah jenis pidana yang cocok dan dapat berjalan efektif. Dalam artian, pidana ta'zîr ini dapat mendidik pelaku, memperbaiki, dan memelihara masyarakat tanpa menghilangkan nilai-nilai keadilan di dalamnya. Dan yang paling penting adalah menepis anggapan masyarakat awam terhadap kewenangan hakim sebagai pengambil keputusan, tidak sebatas menerapkan apa yang ada di dalam al-Qur'an maupun hadis. Tetapi, hakim juga mampu berijtihad sesuai kemampuannya dan tidak keluar dari nilai-nilai keislaman walaupun telah diberikan wewenang yang luas.

Berdasarkan pemaparan kategorisasi pidana bersyarat dalam hukum pidana Islam di atas, dapatlah dicapai suatu jenis pidana dan sistem pemidanaan yang serupa tapi tidak sama. Serupa di sini dengan maksud bahwa, Hukum Pidana Indonesia dan Hukum Pidana Islam memberikan keleluasaan bagi hakim untuk menjatuhkan pidana bagi pelaku tindak pidana yang sesuai dengan tindakan dan keadaan si pelaku. Walaupun di dalam hukum pidana Islam hanya ta'zîr yang memberikan kekuasaan penuh kepada hakim.

Maksud kata 'tidak sama' hanya mengartikan penamaan saja yang berbeda. Namun jika ditelaah lebih dalam, konsep pidana bersyarat dalam hukum pidana Indonesia cakupannya lebih luas. Di mana pidana bersyarat dapat dijatuhkan oleh hakim, jika menurut keyakinannya terdakwa dapat berubah menjadi lebih baik tanpa harus dijebloskan ke penjara. Sejalan dengan itu, dalam hukum pidana Indonesia tidak dibatasi oleh suatu tindak pidana dan ancaman pidananya, yang terpenting hakim ingin menjatuhkan pidana tidak lebih dari satu tahun dan keyakinan hakim tadi. 
Sedangkan dalam hukum pidana Islam, ada 3 poin penting mengenai konsep pidana bersyarat, yaitu:

1. Bahwa, pidana bersyarat dapat dijalankan jika adanya pengampunan dari korban dan/ahli waris,

2. Adanya perdamaian yang terjadi antara kedua belah pihak yang berpekara,

3. Dibenarkan oleh Shar'i (al-Qur'an dan Hadis).

Melihat ketiga poin di atas, bisa didapat sebuah poin yang paling penting yang dapat membuka paradikma orang awam terhadap hukum pidana Islam selama ini membelenggu, yaitu: hukum pidana Islam adalah sistem hukum yang fleksibel serta dinamis. Artinya, hukum pidana Islam tidak melakukan pemidanaan yang monoton, dimana disesuaikan dengan tindak pidana yang dilakukan serta keadaan pelaku pidana. Kecuali, bagi pidana hudûd yang telah ditetapkan oleh Shar'i.

Karena pada intinya bahwa tujuan pokok dalam penjatuhan pidana dalam hukum pidana Islam adalah pencegahan (al-radd wa alzajr) serta pendidikan (al-Islâh wa al-tahdhîb). Maka suatu pemidanaan hendaknya dapat mewujudkan tujuan tersebut. Karena suatu pemidanaan bukan hanya untuk tercapainya sifat efek jeranya saja, tetapi lebih kepada manfaat suatu pidana untuk dapat memperbaiki diri si pelaku setelah ia di pidana.

Suatu pemidanaan akan dikatakan sukses bukan karena beratnya pidana yamg dijatuhkan hakim kepada terpidana. Tetapi lebih kepada keberhasilan hakim dengan keyakinannya menjatuhkan suatu pidana untuk memperbaiki kepribadian pelaku. Sehingga nantinya dapat terwujud sebuah pemahaman dimasyarakat akan tindak pidana atau jarîmah bukan karena takut terhadap pidana yang dikenakan, melainkan lebih kepada kesadaran pribadi dan kebencian terhadap suatu tindak pidana atau jarîmah yang dilarang oleh Allah swt, tentunya agar mendapat keridhaan dari-Nya.

\section{Simpulan}

Pidana bersyarat merupakan sebuah sistem pemidanaan yang mengutamakan perbaikan pelaku agar terhindarnya dari pengaruh yang lebih buruk lagi jika dimasukan kedalam Lembaga Pemasyarakatan (LP). Tetapi tidak mengurangi nilai efek jeranya. Ketentuan pada KUHP telah mengatur pidana bersyarat dapat dijatuhkan, asal hakim dalam 
putusannya menjatuhkan pidana penjara tidak lebih dari satu tahun dan tidak terbatas pada tindak pidana dengan ancaman pidana tertentu. Pada saat dijatuhkannya pidana bersyarat, maka hakim yang memutus perkara tersebut juga langsung memberikan syarat umum dan syarat khusus bagi terpidana. Jadi, pidana bersyarat melakukan pemidanaan terpidana diluar Lembaga Pemasyarakatan (LP) dengan berada dibawah pengawasan jaksa sebagai pelaksana putusan hakim yang telah berkekuatan hukum tetap. Sehingga terpidana diberi kesempatan untuk memperbaiki pribadinya dimasyarakat melalui pidana bersyarat.

Hukum pidana Islam tidak memberikan penamaan yang sama dengan hukum pidana di Indonesia tentang pidana bersyarat, tetapi konsep dan sistem pemidanaan yang diterapkan oleh keduanya dapat dikatakan sama. Ini terlihat dari tujuan yang ingin dicapai dalam sebuah pemidanaan atau penjatuhan pidana. Keduanya bukan didasarkan pada berat atau ringannya suatu ancaman pidana, melainkan proses perbaikan diri yang menjadi tujuannya, yang tentunya tanpa mengurangi nilai-nilai keadilan dan efek jera di dalamnya. Untuk itu pula menjadi penting makna sebuah pidana dan pemidanaan, dimana tanpa adanya suatu tujuan yang konkrit dan nili-nilai luhur yang terkandung di dalamnya dari penjatuhan pidana dan pemidanaan, maka sulit untuk menciptakan sebuah kemaslahatan umum lebih-lebih untuk menciptakan supermasi hukum.

\section{Daftar Rujukan}

Azwar, Syaefuddin. Metode Penelitian. Yogyakarta: Pustaka Pelajar, 2009.

Chazawi, Adami. Pelajaran Hukum Pidana (Bagian 1). Jakarta: PT Raja Grafindo Persada, 2002.

Departemen Agama RI. al-Qur'an dan Terjemahannya. Surabaya: Penerbit CV. Jaya Sakti, 1989.

Hamzah, Andi. Asas-Asas Hukum Pidana. Jakarta: Rineka Cipta, 1994.

Ibn Taimiyah. As-Siyâsah Asy-Shar'iyyah. Kairo: Maktabah Anshar AlMuhammadiyah, 1961.

Ichsan, Muhammad dan M. Endrio Susila. Hukum Pidana Islam: Sebuah Alternatif. Yogyakarta: Lab Hukum Universitas Muhammadiyah Yogyakarta, 2008. 
Lamintang, P.A.F. Hukum Penitensier Indonesia. Bandung: Amrico, 1984.

Mawardi (al-), Abu Al-Hasan Ali. Kitab Al-Ahkâm As-Sultâniyyah. Beirut: Dar Al-Fikr, 1966.

Moeljatno. Kitab Undang-Undang Hukum Pidana. Jakarta: PT. Bumi Aksara, 200.

Muladi. Lembaga Pidana Bersyarat. Bandung: Alumni, 1992.

--------. Kapita Selekta Sistem Peradilan Pidana. Semarang: Badan Penerbit Universitas Diponogoro, 1995.

Muslich, Ahmad Wardi. Pengantar dan Azas-Azas Hukum Pidana Islam Fikih Jinayah. Jakarta: Sinar Grafika, 2004.

-------. Hukum Pidana Islam. Jakarta: Sinar Grafika, 2005.

Prodjodikoro, Wirjono. Asas-asas Hukum Pidana di Indonesia. Bandung: PT. Refika Aditama, 2003.

Rumidi, Sukardi. Metodelogi Penelitian, Petunjuk Praktis Peneliti Pemula. Jakarta: PT Raja Grafindo, 2003.

Sabiq, Sayid. Fikih Sunnah. Jilid 10, Bandung: PT. Alma’arif, 1987.

Saleh, Roeslan. Dari Lembaga Kepustakaan Hukum Pidana. Jakarta: Sinar Grafika, 1998.

Saleh, Roeslan. Stelsel Pidana Indonesia. Jakarta: Aksara Baru, 1983.

Santoso, Muhari Agus. Paradigma Baru Hukum Pidana. Cetakan 1, Yogyakarta: Averroes Press, 2002.

Soekanto, Soerjono dan Mustafa Abdullah. Sosiologi Hukum di dalam Masyarakat. Jakarta: Rajawali, 1987.

Soesilo, R. Pokok-Pokok Hukum Pidana, Peraturan Umum dan Delikdelik Khusus. Bogor: Politea, 1991.

Suharsimi, Arikunto. Prosedur Penelitian Suatu Pendekatan Praktik. Jakarta: Rineka Cipta, 2010.

Syajastani, Abu Dawud bin Sulaiman. Sunnah Abu Dawud. Juz 4, Lebanon: Darul Fiqri, 1993.

Waluyo, Bambang. Penelitian Hukum dalam Praktek. Jakarta: PT. Sinar Grafika, 1996.

Yafi, Alie, dkk. Ensiklopedi Hukum Pidana Islam. Jilid 3, Jakarta: Kharisma Ilmu, 2007. 